\title{
Fly ash induced Morphological, Biochemical and Metal accumulation responses at different developmental stages in Glycine max (L.) Merrill. Revised
}

\author{
Sheikh Ummar Bashir ${ }^{1}$, Manik S. R ${ }^{2}$, Wagay N. A ${ }^{3}$, Mohammad Ayub Shah ${ }^{4}$ \\ Department Of Botany Sant Gadge Baba Amravati University Amravati-444602 \\ ${ }^{1}$ Research Scholar, Department Of Botany, Sant Gadge Baba Amravati University, Amravati, \\ ${ }^{2}$ Retired Professor, Department Of Botany, Sant Gadge Baba Amravati University, Amravati \\ Maharashtra, India. \\ ${ }^{3}$ Research Scholar, Department Of Botany, Vidyabharati Mahavidyalya, Amravati \\ Maharashtra, India., Maharashtra \\ ${ }^{4}$ Assistant Professor, Department Of Botany, Government Degree College Sopore \\ , Baramulla, J\&K India.
}

\begin{abstract}
The research of many previous years has guaranteed the use of fly ash as a material for another green revolution. The present study was channeled to roll up the brilliance of the fly ash in agriculture meticulously. The experiments were conducted in pots of $20 \mathrm{~cm}$ diameter with $6-7 \mathrm{~kg}$ capacity at Department of Botany SGBAU Amravati. The effect of varying levels of fly ash on the morphological and physiological response (protein content, carbohydrates, chlorophyll and carotenoids) of soya bean Glycine max (L.) Merrill. at three growth stages was observed. The varying levels of fly ash prepared with soil were 10\%, 15\%, 20\%, $25 \%, 30 \%$ and a control of only garden soil was maintained. Experimental examination shows a momentous boost in plant biomass, yield and physiological response up to the level of $20 \%$ fly ash from vegetative to pre flowering stage. After post flowering stage reduction in the physiological response was observed probably related to the distribution of nutrients at this stage.
\end{abstract}

Keywords: Agriculture, carbohydrates, Flyash, Glycine max, morphology, photosynthetic pigments proteins.

\section{Introduction}

Coal used as a vital source for the creation of electricity in India is of inferior class producing much more ash about 35-40\%. Right now 118 MT of fly ash is produced per year by near about more than 100 power stations of India and is likely to get in touch with 440 MT per year by 2030. So there is a vital need to defeat this trouble by productive use of fly ash in various fields. The raising financial, human and environmental costs of fly ash management are directing to active support for dandier exercise of the remains of coal fly ash as soil rectification. The fabrication of fly ash in India per year is about more than 100 million tones and this is likely to increase to 175 million in the coming future [1]. By 2017 it is assumed that the annual magnitude of the coal fly ash will be projected to about 225 million tons per year that is going to escort major environmental tribulations [2,3]. Since the independence of India 1947, a speedy enhance has been evident in the generation of electricity, largely supported by coal-based thermal generation constituting about $79 \%$ of total production. On one hand there are diverse management troubles of fly ash as well as demand of land for deposition and storage is a mammoth task, but on the other hand fly ash has proven a valuable useful material for a number of applications [4]. Thus there lies a challenge to convert the threat to opportunity. Fly ash a byproduct of combustible coal has already been accepted as a probable source, for mounting the handiness of mineral nutrients for plant development [5,6,7]. Addition of CCRs neutralized the soil acidity making it suitable for agricultural crops [8]. The operation of fly ash by farmers is so trifling or nothing in most places. The present exercise is intended to generate awareness on exploitation of fly ash in agriculture so to down the percentage of unutilized fly ash and hold up for the sustainable progress.

\section{Materials and methods}

The experiment was accomplished in the green house at Department of Botany Sant Gadge Baba Amravati University, Amravati. The crop plant selected was Glycine max (L.) Merrill., which is the major crop of the area and common food to India, rich in proteins and also major cultivable crop of the Vidharba region of Maharashtra. The high quality seeds of the selected plant were bought from local old cotton market Amravati. Fly ash used in experiment was collected from Rattan India thermal power station, Nandgaon peth, Amravati. Among physical characteristics of both soil and fly ash, water holding capacity and Bulk density of soil/fly ash were figured out by method given by [9]. Moisture percentage was estimated by oven dry method. $\mathrm{pH}$ of the 
soil/ fly ash was assessed as per method of [10], in a soil-water/fly ash water suspension of 1:2 ratio. Organic carbon was calculated by [11] and Total nitrogen by Kjeldahl method. Estimation of total metals was done as per the method given by [12]. The soil/fly ash samples were digested in nitric acid and perchloric acid mixture on hot plate for 2 to 3 hours and the digestate was examined for metals by ICP-AES from SAIF IIT Mumbai and AAS Perkin Elmer from CIC. Experiment was carried out in pots of 6-7 kg capacity with $12 \mathrm{~cm}$ diameter. Five varying concentrations of soil and fly ash were maintained as 10\%, 15\%, 20\%, 25\%, 30\% and a control of only soil was asserted. 15 seeds were sown and germination was observed after 7 days and 10 days. Three replications of each fly ash amended soil and control were maintained. Morphological observations were done at 10-15 days interval. Shoot length, root length by centimeter scale, number of leaves visually, wet biomass and dry biomass of roots and remaining plant were observed after harvesting by digital balance precisa (XB 22A). Leaf area was calculated by graph paper method. The observations concerning the biochemical assay in both stem and leaves were measured at different development stages like vegetative phase, pre-flowering and post flowering stages. The quantification of proteins was done as per the method of [13]. Protein estimation kit from Hi-media (HTBC005) was used. Chlorophyll a, chlorophyll b and total chlorophyll were extracted in $80 \%$ acetone and calculations were performed as per [14] equation. Carotenoids were estimated by [15] method. Total carbohydrate quantification was performed as per anthrone reagent method [16]. The visual densities of proteins, carbohydrates, chl. a, chl. b and carotenoids were taken by Perkin Elmer lambda 25 UV/Visible spectrophotometer at 660,620,665, 645 and $450 \mathrm{~nm}$ respectively.

\section{Data analysis}

All observations concerning biochemical response and morphological parameters of the experiment were repeated thrice and the data taken was analyzed through ANOVA at $95 \%$ confidence interval through Graph pad Prism version 7.

\section{Results}

The physical and chemical properties of the soil/fly ash are shown in Table 1(a) and 1(b) respectively.fly ash was found to be alkaline in nature ( $\mathrm{pH} 7.2)$ likening soil that was slight acidic ( $\mathrm{pH}$ 6.5). The nutrient elements like nitrogen $(0.56 \%)$ in fly ash were almost near to that of soil $(0.61 \%) . \mathrm{Mg}$ in fly ash was more comparing soil but phosphorous was to lesser than that of soil.

\section{Effect on seed germination:}

Germination is a principal plant growth process that capers a major part in determining subsequent yield and growth. The essence of respective doses of fly ash incorporation soil on germination is depicted in Table 2. Germination was recorded after 7 days and 10 days. The germination in control pot and $10 \%$ fly ash meliorated pot shows $100 \%$ germination rate after 7 days but as the fly ash step up in concentration, the germination shows a gradual slump that was $93.33 \%$ in 15 to $20 \%$ fly ash concentration and $85.71 \%$ in 25 and $30 \%$ concentrations. After the observation of 10 days $15 \%$ and $20 \%$ fly ash doses too shows $100 \%$ germination but $20 \%$ and $30 \%$ doses witness a gradual decay in germination that indicates that fly ash delays the germination if used in more concentration.

\section{Effect on Morphology:}

The parameters in concern with morphology are interpreted in Table 3(a) and 3(b). Regarding the height of plant, it was less in control but promoted with the increase in fly ash concentration reaches utmost in $20 \%$ and then again shows a decrement in $25 \%$ to $30 \%$ fly ash but was still more than control. Fresh and dry biomass of both roots and remaining plant shows a substantial increase in $20 \%$ of the fly ash dose. Root length was raised from control to $30 \%$, maximum in $25 \%$ but root girth was more in 15 to $20 \%$ by visual observations. The leaf number also enhanced from control to $30 \%$ but maximum in $20 \%$ fly ash concentration. Leaf size depicts significant rise from $18.233 \pm 2.750 \mathrm{~cm}^{2}$ in control up to $57.333 \pm 7.522 \mathrm{~cm}^{2} 20 \%$ dose. The final yield of seeds was also more in $20 \%$ fly ash concentration. The variation in morphology and yield in plants grown in different fly ash concentration is shown by photo plate (Fig 4a,b,c,d,e).

\section{Effect on photosynthetic pigment:}

The impact of different concentrations of fly ash on leaf photosynthetic pigments chl a, clh $\mathrm{b}$ and total chl in vegetative phase confirms constant increase from control to $20 \%$ of the fly ash concentration but declined as the fly ash concentration increased above $20 \%$. In pre flowering stage the alike observations were ascertained but in post flowering phase all three photosynthetic pigments depicts a gradual decrease but the concentration was still more in $10 \%, 15 \%, 20 \%$ than control. The carotenoids were also recorded more in all other concentrations than control in all the three phases with maximum in $20 \%$ fly ash dose. The detailed results of chl a, chl b and total chl in vegetative, pre flowering and post flowering phases are interpreted through graphs 
Fig. 1(a), 1(b) and 1(c) respectively. The carotenoid concentration is depicted by graphical representation as Fig. $1(\mathrm{~d})$.

\section{Effect on biomolecules:}

The observations of carbohydrate concentration in both stem, leaf are shown by graph Fig. 2(a) and Fig. 2(b) respectively. The carbohydrate concentration both in stem and leaves is maximum at $20 \%$ in all vegetative, pre flowering and post flowering phase. The post flowering phase shows a gradual decrease in all concentrations than pre flowering phase, but not less than vegetative phase. Similar observations were found in protein concentration depicted its maximum range in $20 \%$ fly ash concentration in both leaves and stem in all three phases. Shown by graphical representation Fig. 3(a) and 3(b) respectively.

\section{Accumulation of elements:}

Amongst all micro and macro nutrients the uptake and concentration, increases considerably in fly ash amended soils in both stems as well as in leaves as compared to control. All the elements $\mathrm{N}, \mathrm{K}, \mathrm{Mg}, \mathrm{Cu}, \mathrm{Fe}, \mathrm{M}$, $\mathrm{Cr}, \mathrm{Co}$ and $\mathrm{Zn}$ show a significant increase in ash ameliorated soils other than control in stem samples. The growth of plants was significant up to $20 \%$ of fly ash ameliorated soil. However it shows a gradual decline in above fly ash grades of beyond $20 \%$, may be because of the increasing concentration of elements in soil medium. the data is interpreted through Table 4.

\section{Discussion}

The exploitation of fly ash in agriculture is because of its mineral content [17,18]. The result of the physicochemical analysis of fly ash indicated that fly ash has an alkaline $\mathrm{pH}$, which may be by the occurrence of oxides of $\mathrm{Ca}$ and $\mathrm{Mg}$ with acid neutralizing properties. The application of fly ash leads to enhance the growth and yield of crop plants in crops like alfalfa, barley, Bermuda grass and white clover [19.20,21,22].The germination percentage of seeds showed gradual and constant decrease as the fly ash application was enhanced in soil. The studies of [23] also reported that the germination percentage decreases as the concentration of fly ash application is more. The results showed a significant increase in both growth parameters like height of plant, dry and fresh weight of roots and shoot, leaf number and leaf size as well as physiological observations from control up to $30 \%$ of the fly ash concentration. Similar findings were carried out by [24] in leguminous crops which depicted substantial increase in growth and physiological parameters from control up to $50 \%$ of fly ash. The study reveals that the percentage of germination and the growth parameters were found to be increased at $20 \%$ fly ash and beyond that it gradually decreases. Hence $20 \%$ fly ash concentration can be used for the growth of plants. The beneficial effect of fly-ash at lower level (10-30\%) has already been observed [25] on vigna mungo. There have also been some workers whose results showed that fly ash exploited at the rate of $20 \%$ proved beneficial for many crops like soybean, cabbage, chick pea, cucumber, lentil, maize, potato, wheat, tomato etc [26.27.28,29,30]. The biochemical analysis of experimental plant also showed a significant increase in photosynthetic pigments chl a, chl b total chl and carotenoids in $20 \%$ fly ash concentration comparing control. The work of [31] depicted positive influence of $10 \%$ of fly ash on photosynthetic pigments of two plants Andrographis paniculata, Coleus forskohlii. one of the report that fly ash used in his investigation clearly indicates the presence of huge amount of $\mathrm{K}$ and was proven beneficial for palak, mung bean and chili plants up to $25 \%$ [32]. Protein content and nitrate reductase activity was also reported to increase under low $25 \%$ fly ash application as compared to control [33]. It is evident from the observations that the content of nitrogen in soil is a little more than in fly ash as $0.61 \%$ and $0.56 \%$, respectively, a similar study was done by [34] which correlate the present study. Nutrient uptake by the plants increased up to $20 \%$ fly ash amended soil and there by yielding better results for increasing Biomass and physiological qualities of plant moreover [35] also reported that nutrients show an increase in up take up to $20 \%$ fly ash. Thus fly ash can be used as an eco friendly non conventional fertilizer $20 \%$ for Soyabean, because it will improve growth, yield and biochemical factors of the plant and side by side the disposal problem of huge amount of fly ash will be solved.

\section{Conclusion}

Based on the above interpretation and reports, it can be concluded that there is a vast scope of fly ash exploitation in agriculture without any deleterious effect. But the physical and chemical properties of fly ash vary according to coal mine areas. Therefore the approach to exploit it in agriculture is different and very much dependent on the characteristics of soil or soil type. The present study also proposes careful probe of the accretion of heavy metals (present in fly ash) in soil and in edible portion of crops. 


\section{References}

[1]. Jamwal N, (2003). Looks the ways to utilize fly ash. Down to earth, 12(3): 1-5.

[2]. Asokan P, Saxena M and Asolekar SR, (2005). "Coal Combustion Residues Environmental Implications and Recycling Potentials", Resources, Conservation \& Recycling. 43: 239-252.

[3]. Sachdev RK, (2007). "Clean Coal Technologies - Indian Scenario", Third International Conference on Clean Coal Technologies for Our Future, Sardinia, Italy.

[4]. Arivazhagan K, Ravichandran M, Dube SK, Mathur VK, Ram KK, Yagnanarayana K, Kamal PMM, Sinha AK, Sarangi BD, Tripathi VKM, Gupta SK, Rajvir S, Mushtaq A, Thakur AS and Raghvendra N, (2011). Effect of the coal fly ash on agriculture crops: showcase project on use of fly ash in agriculture in and around thermal power station areas of national thermal power corporation Ltd., India. world of fly ash (WOCA) conference, in Denver,co,USA.

[5]. BN. Mittra, S. Karmakar, DK. Swain and BC. Ghosh, Fly ash a potential source of soil amendment and a component of integrated plant nutrient supply system. Fuel, 84 2005, 447-1451.

[6]. CH. Lee, YB. Lee, H. Lee and PJ Kim, Reducing phosphorus release from paddy soils by a fly ash gypsum mixture. Bioresource Technol. 98, 2007, 1980-1984.

[7]. VC. Pandey and N. Singh, Impact of fly ash incorporation in soil systems. Agriculture Ecosystem and Environment. 136, 2010,

[8]. AM. Molliner and JJ. Street, Effect of CCRs and lime on growth and composite of corn on acid sandy soils. In: Proc. Soil crop science society Florida. 41, 1982, 217-220.

[9]. CA. Black, (Editor-in-Chief), DD. Evans, JL. White, LE. Ensmingher and FE.Clarke, Associate Editors and RC. Dinauer, Managing Editor, Methods of Soil Analysis. Part 2-Chemical and Microbiological Properties, 9 Series Agronomy. American Society of Agronomy, Inc., Madison, Wisconsin, USA, 1965.

[10]. ML. Jackson, Soil Chemical Analysis. Asia Publishing House, Bombay, 1967.

[11]. A. Walkley and IA. Black, An Examination of Degtjareff Method for Determining Soil Organic Matter and a Proposed Modification of the Chromic Acid Titration Method. Soil Sci. 37, 1934, 29-37.

[12]. AL. Page, Methods of Soil Analysis Part II. Soil Sci. Society of America, Madison, Wisconsin, 1982

[13]. OH. Lowry, NJ. Rosebrough, AL. Farr and RJ. Randall, Protein Measurement with the Folin Phenol Reagent. J. Biol. Chem. 193, 1951, 265-275.

[14]. D. Arnon, Plant Physiology 24, 1949, 1- 15.

[15]. JB. Harborne, Phytochemical Methods. Chapman and Hall, Ltd., London, pp. 49-188, 1973

[16]. S. Sadashivam, A. Manikam, Biochemical methods. Second edition reprint. New age international (P) limited publishers, Ansari road, Darya gang, New delhi-110002, 2005, 8-10.

[17]. N. Kalra, HC. Joshi, A. Chaudhary, R. Chaudhary and SK. Sharma, Impact of fly ash incorporation in soil on germination of crops. Bioresource. Technology, 61, 1997, 39-41.

[18]. SN. Singh, K. Kulshreshtha and KJ. Ahmad, Impact of fly ash soil amendment on seed germination, seedling growth and metal composition of Vicia faba L. Ecological. Engineering. 9, 1997, 203-208.

[19]. MJ. Hill and CA. Lamp, Use of pulverized fuel ash from Victorian brown coal as a source of nutrients for pasture species. Aust. J. Exptl. Agric. Animal Husb. 20, 1980, 377-84

[20]. AA. Elseewi, AL. Page and SR. Grimm, Chemical characterization of fly ash aqueous systems. J. Environ. Qual, 9, 1980a, 424-428.

[21]. AA. Elseewi, I. Straughan and AL. Page, Sequential cropping of fly ash amended soils. Effects on soil chemical properties and yield and elemental composition of plants. Sci. Tot. Environ, 15, 1980b, 247-259.

[22]. LH. Weinstein, JF. Osmeloski, M. Rutzke, AO. Beers, JB. McCahan, CA. Bache and DJ. Lisk, Elemental analysis of grasses and legumes growing on soil covering coal fly ash landfill sites. J. Food Safety, 9, 1989, 291-300.

[23]. SC. Swain, SK. Padhi and D. Sahoo, Effect of coal ash on physio-morphological and biochemical characters of okra (Abelmoschus esculentus L.) moench. The Bioscan. 9(2), 2014, 653-657.

[24]. SD. Muduli, N. Chaturvedi, P. Mohapatra, NK. Dhal and BD Nayak, Growth and Physiological Activities of Selected Leguminous Crops Grown in Carbonated Fly Ash Amended Soil. Greener Journal of Agricultural Sciences. 4 (3), 2014, 083-90.

[25]. GS. Behera, RK. Mohanta, PK. Swain, MK. Panda and SB. Padhi, Effect of fly ash as a carrier material with bga inoculants on seedling growth and pigmentation of vigna mungo L. International joural of biology, pharmacy and applied science, 4(1), 2015, 94100.

[26]. MR. Khan and MW. Khan, Effect of fly ash on growth and yield of tomato. Environment. Pollut, 91, 1996, 105-111.

[27]. LC. Mishra, and KN. Shukla, Effects of fly ash deposition on growth, metabolism dry matter production in maize and soyabean. Environ. Pollut, 42, 1986, 1-13.

[28]. D. Raghav and AA. Khan, Impact of industrial particulate pollutants applied to soil on growth and yield of tomato. Thai, Agric. Sci, 35, 2002, 187-194.

[29]. SK. Singh, Studies on interaction of air pollutants and root-knot nematodes on some pulse crops, PhD Thesis, Aligarh Muslim University, Aligarh, India, 1989.

[30]. LC. Ram and RE. Masto, (2010). An appraisal of the potential use of fly ash for reclaiming coal mine so. J. Environ. Manag, 91, 2010, 603-617.

[31]. S. Deepak, S. Shailesh and MK. Dwivedi, The impact of fly ash on photosynthetic activity and medicinal property of plants. International journal of current microbiology and applied sciences. 2(8), 2013, 382-388.

[32]. D. Katiyar, A. Singh, P. Malaviya, D. Pant, G. Abraham and SK. Singh, (2012). Impact of fly ash amended soil on growth and yield of crop plants. Int j. Environmental and waste management. 10(2/3), 2010, 150-162.

[33]. J. Qurratula, K. Sumira, Riyazzuddin, Mahmooduzzafara and TO. Siddiqia, Soil amendments of fly ash: effects on function and biochemical activity of Carthamus tinctorius L. plants. Israel Journal of Plant Sciences. DOI:10.1080/07929978.2014.945313, 2014, $1-13$.

[34]. T. Cafer, M. Nuray and U. İsmet, Effect of Fly Ash Applications on Heavy Metal Contents of Soil and Corn Plant (Zea mays L.) Türk Tarım ve Doğa Bilimleri Dergisi, 2(1), 2015, 92-98.

[35]. RC. Doongar \& A. Ghosh, (2013). Bioaccumulation of nutrient elements from fly ash-amended soils in Jatropha curcas L. a biofuel crop. Environ Monit Assess, 185(2), 2013, 6705-6712. 
Table1(A). Physical Characteristics Of Soil And Fly Ash

$\mathrm{Bd}=$ Bulk Density, Whc=Water Holding Capacity, $\mathrm{M}=$ Moisture \%Age, Por=Porosity

\begin{tabular}{lcccc}
\hline & BD cm3 & WHC & M \%age & POR \\
\hline Soil & 1.04 & $67.74 \%$ & 31.48 & 1.21 \\
Fly ash & 1.21 & $64.54 \%$ & 36.50 & $51.24 \%$ \\
& & & & \\
\hline
\end{tabular}

Table 1(b). Chemical characteristics of soil and fly ash in $\mathrm{mg} / \mathrm{kg}$ except OC \& $\mathrm{n}$ in $\%$ (nd)= less than=0.01 $\mathrm{mg} / \mathrm{l}$, $(---)=$ not estimated

\begin{tabular}{|c|c|c|}
\hline Properties & Soil & Fly ash \\
\hline $\mathrm{pH}$ & 6.50 & 7.20 \\
\hline OC\% & 0.9 & 0.43 \\
\hline $\mathrm{N} \%$ & 0.61 & 0.56 \\
\hline $\mathrm{P}$ & 24.58 & 34.51 \\
\hline K & 78.51 & 103.38 \\
\hline S & 16.51 & 15.58 \\
\hline $\mathrm{Ca}$ & 8.00 & 7.500 \\
\hline $\mathrm{Mg}$ & 21.71 & 27.30 \\
\hline $\mathrm{Cr}$ & 5.55 & 7.26 \\
\hline $\mathrm{Cu}$ & 10.48 & 14.26 \\
\hline $\mathrm{Fe}$ & 68.96 & 71.34 \\
\hline Mn & 18.61 & 15.52 \\
\hline $\mathrm{Ni}$ & .035 & 3.417 \\
\hline $\mathrm{Co}$ & 4.66 & 2.19 \\
\hline $\mathrm{Gr}$ & ND & $\cdots$ \\
\hline $\mathrm{Li}$ & 3.80 & $\cdots$ \\
\hline V & 2.50 & $\cdots$ \\
\hline $\mathrm{AL}$ & 493.12 & 15.06 \\
\hline B & 0.33 & 21.00 \\
\hline $\mathrm{Ba}$ & 9.09 & 29.55 \\
\hline $\mathrm{Pb}$ & 0.839 & ND \\
\hline Sr & 5.55 & 17.00 \\
\hline $\mathrm{Ti}$ & 14.95 & 1.35 \\
\hline Mo & $\mathrm{ND}$ & 6.00 \\
\hline $\mathrm{Se}$ & ND & ND \\
\hline As & ND & 2.00 \\
\hline
\end{tabular}

Table 2. Effect of Fly ash on germination

\begin{tabular}{|c|c|c|c|}
\hline \multirow{2}{*}{ Treatment } & \multirow{2}{*}{ Seeds sown } & \multicolumn{2}{|c|}{ Seed germination $(\%)$} \\
\hline & & 7 days & 10 days \\
\hline $\mathrm{C}$ & 15 & 100 & 100 \\
\hline 10 & 15 & 100 & 100 \\
\hline 15 & 15 & 93.33 & 100 \\
\hline 20 & 15 & 93.33 & 100 \\
\hline 25 & 15 & 85.71 & 86.66 \\
\hline 30 & 15 & 85.71 & 85.71 \\
\hline
\end{tabular}


Fly Ash Induced Morphological, Biochemical And Metal Accumulation...

Table 3(a). Effect of fly ash on height $(\mathrm{cm})$ of plant and leaf number. The experimental set was repeated three times. Mean within columns are significant at $\mathrm{p}<0.05$. $\mathrm{C}=$ control and 10,15,20,25,30 are treatments in \%age.

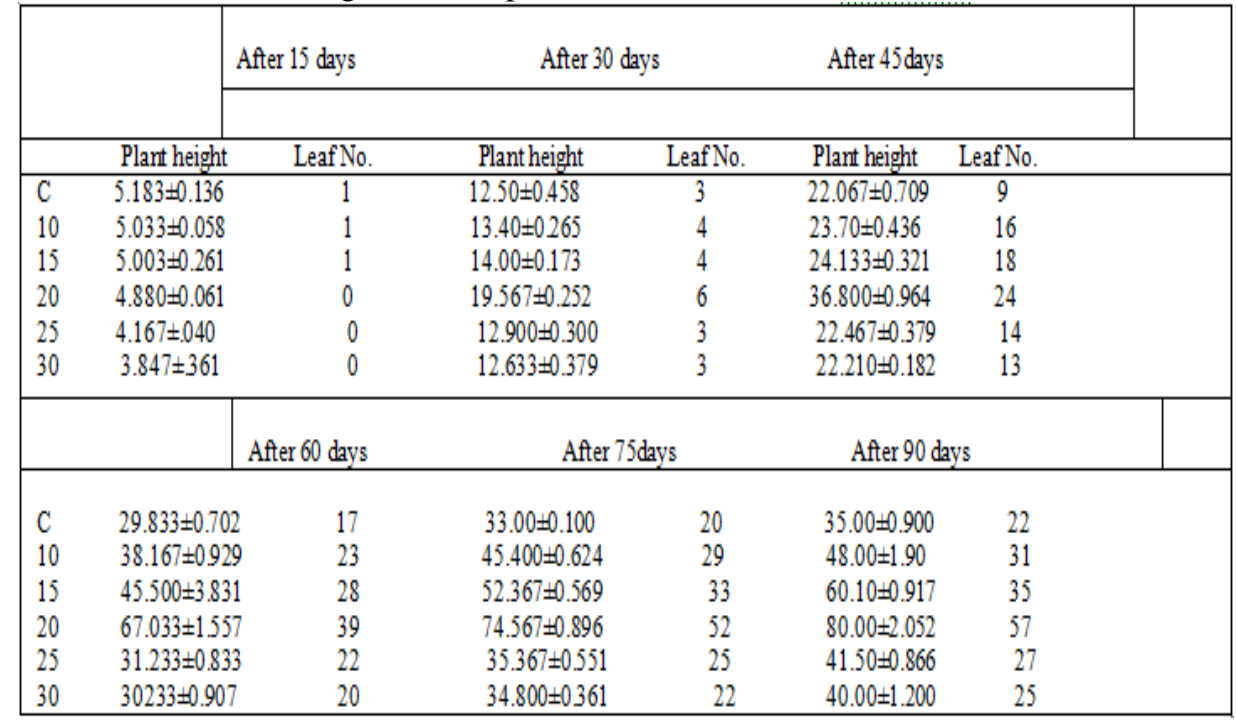

Table 3(b). Effect of fly ash on root length, fresh and dry biomass of root and remaining plant. Rl(root length $\mathrm{cm})$, fwr(fresh weight of root gm), dwr(dry weight of root gm), fwl+s(fresh weight of leaf and shoot gm). The experimental set was repeated three times. Mean within columns are significant at $\mathrm{p}<0.05$.

\begin{tabular}{lcccccc} 
& $\mathrm{C}$ & $10 \%$ & $15 \%$ & $20 \%$ & $25 \%$ & $30 \%$ \\
\hline RL & $11.837 \pm 0.415$ & $19.733 \pm 1.102$ & $17.680 \pm 0.193$ & $17.500 \pm 0.173$ & $20.330 \pm 0.580$ & $16.433 \pm 0.306$ \\
FWR & $0.711 \pm 0.017$ & $1.850 \pm 0.035$ & $2.873 \pm 0.055$ & $3.775 \pm 0.013$ & $1.270 \pm 0.026$ & $0.920 \pm 0.020$ \\
DWR & $0.387 \pm 0.006$ & $0.877 \pm 0.015$ & $1.453 \pm 0.051$ & $1.773 \pm 0.025$ & $0.648 \pm 0.022$ & $0.436 \pm 0.006$ \\
FWL+S & $7.397 \pm 0.317$ & $15.653 \pm 0.350$ & $21.20 \pm 0.458$ & $36.607 \pm 0.447$ & $10.593 \pm 0.559$ & $8.533 \pm 0.628$
\end{tabular}

Table no.4. Accumulation of micro and macro nutrients in ppm by root and stem of Glycine max. The observations are mean of three readings with standard deviation. Mean within columns are significant at $\mathrm{p}<0.05$.alphabetes $=$ symbols of elements, $\mathrm{c}=$ control and 10,15,20,25,30 are treatments in \%age.

\begin{tabular}{|c|c|c|c|c|c|c|c|c|c|c|}
\hline \multicolumn{11}{|c|}{ Root } \\
\hline & $\mathrm{N} \%$ & $\mathrm{~K}$ & $\mathrm{Mg}$ & $\mathrm{Fe}$ & Mn & $\mathrm{Cu}$ & $\mathrm{Cd}$ & $\mathrm{Cr}$ & $\mathrm{Co}$ & $\mathrm{Zn}$ \\
\hline \multirow[t]{2}{*}{$\mathrm{C}$} & $\ldots$ & 51.24 & 12.16 & 8.16 & 5.22 & 1.97 & 0.77 & 1.17 & 0.22 & 2.52 \\
\hline & & \pm 0.33 & \pm 0.13 & \pm 0.05 & \pm 0.02 & \pm 0.02 & \pm 0.04 & \pm 0.01 & \pm 0.01 & \pm 0.02 \\
\hline \multirow[t]{2}{*}{10} & $\ldots$ & 53.18 & 13.06 & 9.92 & 7.16 & 2.15 & 0.96 & 2.19 & 0.54 & 3.06 \\
\hline & & \pm 0.02 & \pm 0.06 & \pm 0.02 & \pm 0.00 & \pm 0.003 & \pm 0.01 & \pm 0.03 & \pm 0.04 & \pm 0.02 \\
\hline \multirow[t]{2}{*}{15} & $\ldots$ & 53.77 & 13.49 & 10.12 & 7.46 & 2.30 & 0.99 & 2.37 & 0.66 & 3.31 \\
\hline & & \pm 0.08 & \pm 0.04 & \pm 0.04 & \pm 0.05 & \pm 0.02 & \pm 0.004 & \pm 0.04 & \pm 0.02 & \pm 0.05 \\
\hline \multirow[t]{2}{*}{20} & $\ldots$ & 54.07 & 15.64 & 10.47 & 7.77 & 2.66 & 1.004 & 3.21 & 0.72 & 3.65 \\
\hline & & \pm 0.02 & \pm 0.49 & \pm 0.19 & \pm 0.01 & \pm 0.06 & \pm 0.004 & \pm 0.01 & \pm 0.01 & \pm 0.03 \\
\hline \multirow[t]{2}{*}{25} & ... & 54.27 & 15.92 & 10.80 & 7.87 & 3.22 & 1.06 & 3.61 & 0.88 & 3.87 \\
\hline & & \pm 0.01 & \pm 0.01 & \pm 0.01 & \pm 0.04 & \pm 0.004 & \pm 0.01 & \pm 0.01 & \pm 0.03 & \pm 0.04 \\
\hline \multirow[t]{2}{*}{30} & $\ldots$ & 54.98 & 16.45 & 10.96 & 8.12 & 3.42 & 1.12 & 3.86 & 0.98 & 3.97 \\
\hline & & \pm 0.01 & \pm 0.01 & \pm 0.03 & \pm 0.003 & \pm 0.01 & \pm 0.01 & \pm 0.04 & \pm 0.03 & \pm 0.02 \\
\hline \multicolumn{11}{|c|}{ Stem } \\
\hline \multirow[t]{2}{*}{$\mathrm{C}$} & 0.10 & 13.63 & 4.19 & 2.01 & 1.17 & 0.20 & 0.10 & 0.24 & 0.06 & 0.27 \\
\hline & \pm 0.001 & \pm 0.50 & \pm 0.01 & \pm 0.01 & \pm 0.05 & \pm 0.01 & \pm 0.003 & \pm 0.002 & \pm 0.001 & \pm 0.10 \\
\hline \multirow[t]{2}{*}{10} & 0.16 & 14.26 & 5.25 & 3.18 & 1.24 & 0.36 & 0.14 & 0.37 & 0.07 & 0.34 \\
\hline & \pm 0.01 & \pm 0.03 & \pm 0.04 & \pm 0.03 & \pm 0.02 & 0.01 & \pm 0.01 & \pm 0.05 & \pm 0.002 & \pm 0.03 \\
\hline \multirow[t]{2}{*}{15} & 0.18 & 14.85 & 5.63 & 3.38 & 1.58 & 0.44 & 0.23 & 0.43 & 0.09 & 0.42 \\
\hline & \pm 0.01 & \pm 0.04 & \pm 0.01 & \pm 0.03 & \pm 0.05 & \pm 0.02 & \pm 0.02 & \pm 0.01 & \pm 0.00 & \pm 0.003 \\
\hline \multirow[t]{2}{*}{20} & 0.20 & 15.62 & 5.83 & 3.67 & 2.44 & 0.55 & 0.30 & 0.50 & 0.10 & 0.62 \\
\hline & \pm 0.01 & \pm 0.002 & \pm 0.02 & \pm 0.02 & \pm 0.01 & \pm 0.03 & \pm 0.01 & \pm 0.004 & \pm 0.001 & \pm 0.08 \\
\hline \multirow[t]{2}{*}{25} & 0.19 & 15.77 & 5.89 & 3.89 & 2.65 & 0.72 & 0.38 & 0.51 & 0.11 & 0.70 \\
\hline & \pm 0.002 & \pm 0.02 & \pm 0.02 & \pm 0.002 & \pm 0.002 & \pm 0.002 & \pm 0.02 & \pm 0.01 & \pm 0.001 & \pm 0.004 \\
\hline
\end{tabular}


Fly Ash Induced Morphological, Biochemical And Metal Accumulation...

\begin{tabular}{|c|c|c|c|c|c|c|c|c|c|c|}
\hline 30 & $\begin{array}{l}0.18 \\
\pm 0.01\end{array}$ & $\begin{array}{c}16.01 \\
\pm 0.02\end{array}$ & $\begin{array}{l}5.99 \\
\pm 0.01\end{array}$ & $\begin{array}{c}4.15 \\
\pm 0.06\end{array}$ & $\begin{array}{c}2.72 \\
\pm 0.05\end{array}$ & $\begin{array}{c}0.80 \\
\pm 0.01\end{array}$ & $\begin{array}{c}0.40 \\
\pm 0.02\end{array}$ & $\begin{array}{l}0.59 \\
\pm 0.01\end{array}$ & $\begin{array}{c}0.14 \\
\pm 0.02\end{array}$ & $\begin{array}{c}0.77 \\
\pm 0.03\end{array}$ \\
\hline \multicolumn{11}{|c|}{ Leaf } \\
\hline $\bar{C}$ & $\begin{array}{l}0.29 \\
\pm 0.01\end{array}$ & $\begin{array}{r}40.12 \\
\pm 0.003\end{array}$ & $\begin{array}{r}9.73 \\
\pm 0.53\end{array}$ & $\begin{array}{c}6.20 \\
\pm 0.01\end{array}$ & $\begin{array}{c}4.12 \\
\pm 0.01\end{array}$ & $\begin{array}{c}0.92 \\
\pm 0.01\end{array}$ & $\begin{array}{r}0.43 \\
\pm 0.01\end{array}$ & $\begin{array}{r}0.56 \\
\pm 0.002\end{array}$ & $\begin{array}{r}0.20 \\
\pm 0.003\end{array}$ & $\begin{array}{r}1.01 \\
\pm 0.01\end{array}$ \\
\hline 10 & $\begin{array}{r}0.32 \\
\pm 0.001\end{array}$ & $\begin{array}{l}41.36 \\
\pm 0.02\end{array}$ & $\begin{array}{l}10.32 \\
\pm 0.01\end{array}$ & $\begin{array}{r}6.95 \\
\pm 0.04\end{array}$ & $\begin{array}{c}5.21 \\
\pm 0.03\end{array}$ & $\begin{array}{c}1.25 \\
\pm 0.02\end{array}$ & $\begin{array}{c}0.59 \\
\pm 0.05\end{array}$ & $\begin{array}{r}0.81 \\
\pm 0.01\end{array}$ & $\begin{array}{r}0.31 \\
\pm 0.003\end{array}$ & $\begin{array}{c}1.13 \\
\pm 0.01\end{array}$ \\
\hline 15 & $\begin{array}{c}0.32 \\
\pm 0.01\end{array}$ & $\begin{array}{l}41.83 \\
\pm 0.01\end{array}$ & $\begin{array}{l}10.49 \\
\pm 0.02\end{array}$ & $\begin{array}{r}7.20 \\
\pm 0.07\end{array}$ & $\begin{array}{c}5.39 \\
\pm 0.04\end{array}$ & $\begin{array}{c}1.42 \\
\pm 0.02\end{array}$ & $\begin{array}{c}0.6 \\
\pm 0.01\end{array}$ & $\begin{array}{r}0.90 \\
0.003\end{array}$ & $\begin{array}{r}0.42 \\
\pm 0.01\end{array}$ & $\begin{array}{r}1.28 \\
\pm 0.01\end{array}$ \\
\hline 20 & $\begin{array}{l}0.38 \\
\pm 0.0\end{array}$ & $\begin{array}{l}42.10 \\
\pm 0.09\end{array}$ & $\begin{array}{l}11.15 \\
\pm 0.04\end{array}$ & $\begin{array}{r}7.66 \\
\pm 0.02\end{array}$ & $\begin{array}{c}5.89 \\
\pm 0.06\end{array}$ & $\begin{array}{r}1.75 \\
\pm 0.05\end{array}$ & $\begin{array}{r}0.70 \\
\pm 0.004\end{array}$ & $\begin{array}{r}0.94 \\
\pm 0.03\end{array}$ & $\begin{array}{r}0.53 \\
\pm 0.08\end{array}$ & $\begin{array}{c}1.61 \\
\pm 0.03\end{array}$ \\
\hline 25 & $\begin{array}{c}0.41 \\
\pm 0.01\end{array}$ & $\begin{array}{l}42.40 \\
\pm 0.50\end{array}$ & $\begin{array}{c}11.59 \\
\pm 0.07\end{array}$ & $\begin{array}{r}7.95 \\
\pm 0.03\end{array}$ & $\begin{array}{r}5.75 \\
\pm 0.03\end{array}$ & $\begin{array}{r}1.90 \\
\pm 0.02\end{array}$ & $\begin{array}{l}0.76 \\
\pm 0.01\end{array}$ & $\begin{array}{r}1.11 \\
\pm 0.003\end{array}$ & $\begin{array}{r}0.60 \\
\pm 0.003\end{array}$ & $\begin{array}{c}2.15 \\
\pm 0.04\end{array}$ \\
\hline 30 & $\begin{array}{c}0.42 \\
\pm 0.01\end{array}$ & $\begin{array}{l}42.64 \\
\pm 0.04\end{array}$ & $\begin{array}{l}12.57 \\
\pm 0.05\end{array}$ & $\begin{array}{c}8.30 \\
\pm 0.05\end{array}$ & $\begin{array}{r}5.73 \\
\pm 0.04\end{array}$ & $\begin{array}{r}2.19 \\
\pm 0.36\end{array}$ & $\begin{array}{r}0.92 \\
\pm 0.02\end{array}$ & $\begin{array}{r}1.21 \\
\pm 0.002\end{array}$ & $\begin{array}{r}0.71 \\
\pm 0.01\end{array}$ & $\begin{array}{c}2.41 \\
\pm 0.02\end{array}$ \\
\hline
\end{tabular}

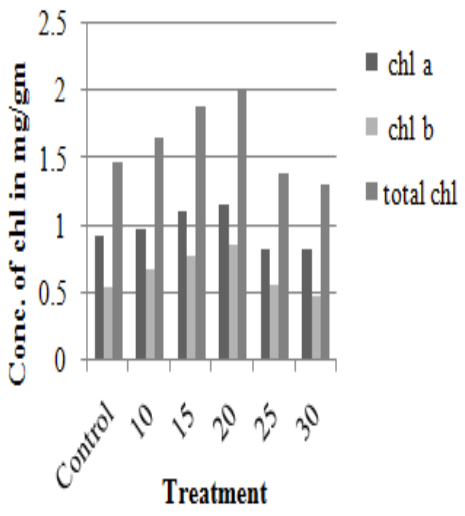

Fig.l(a)vegetative phase

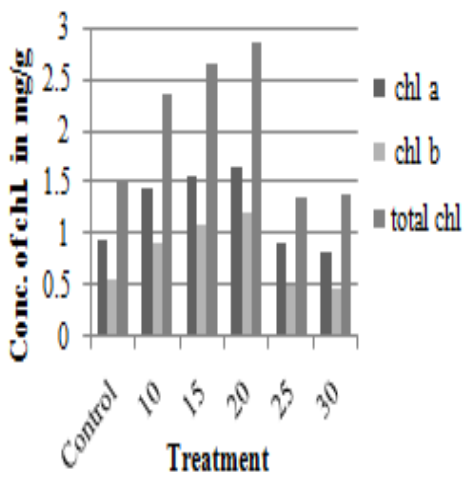

Fig, 1(c) post flowering stage
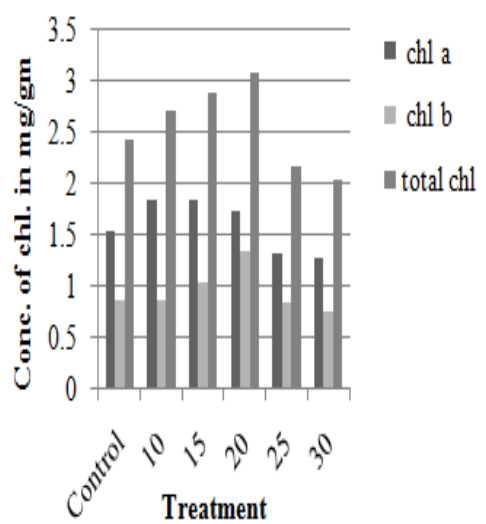

Treatment

Fig.l(b)pre flowering stage

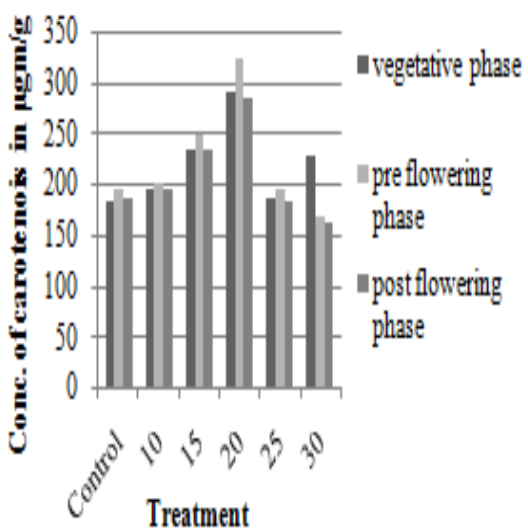

Fig,1(d) all three phases 


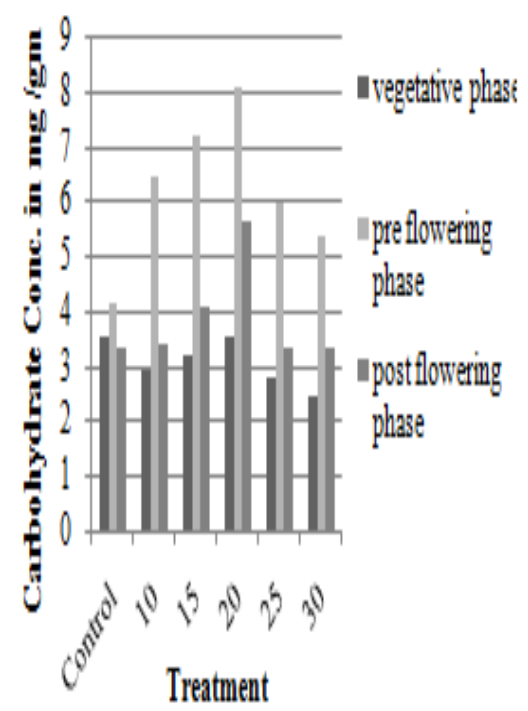

Figo,(a) all three phases of stem
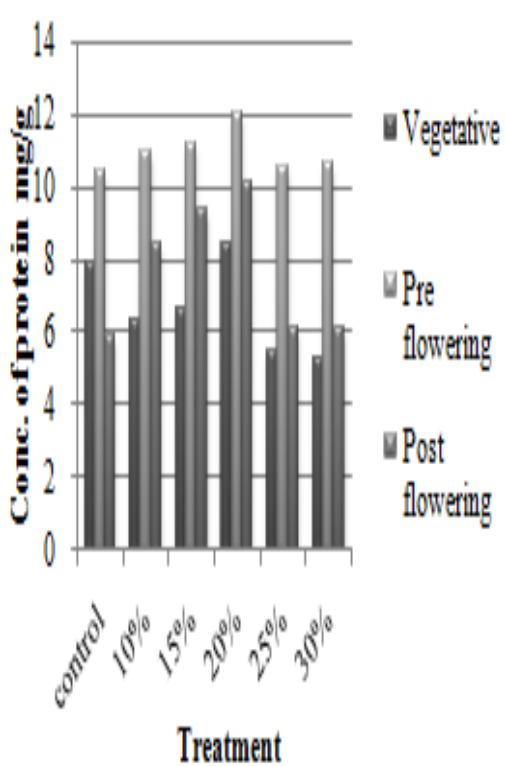

Figig)(a) all three phases of leares

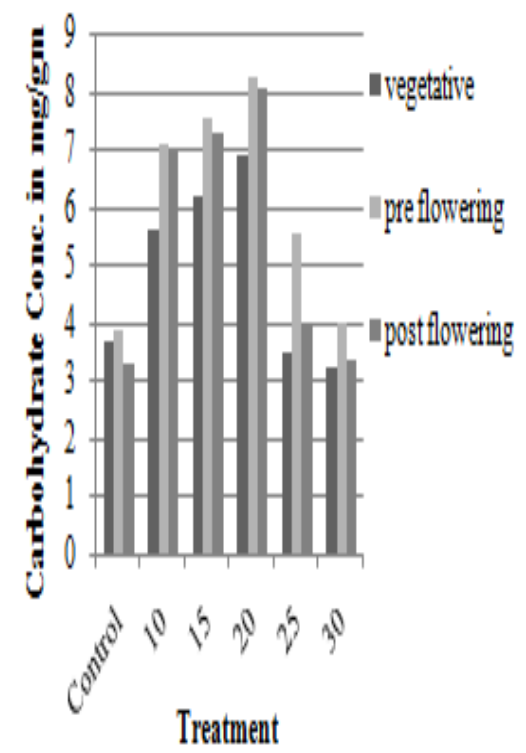

Fig.?(b) all three phases of leaf

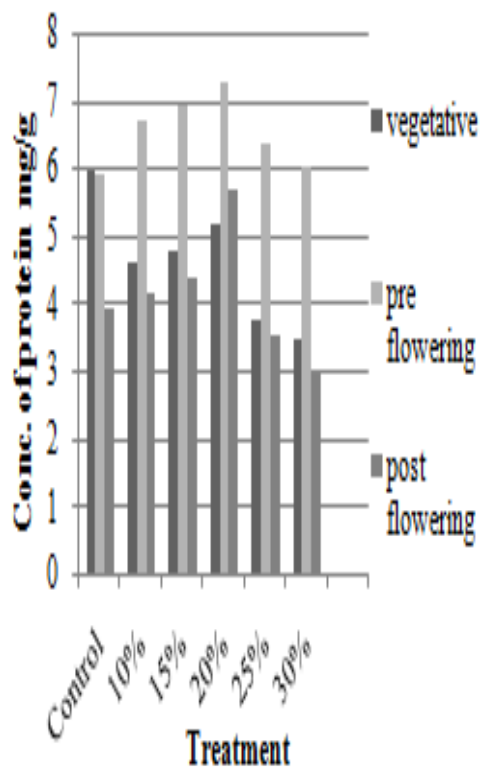

Figig,(b) all three phases of stem 


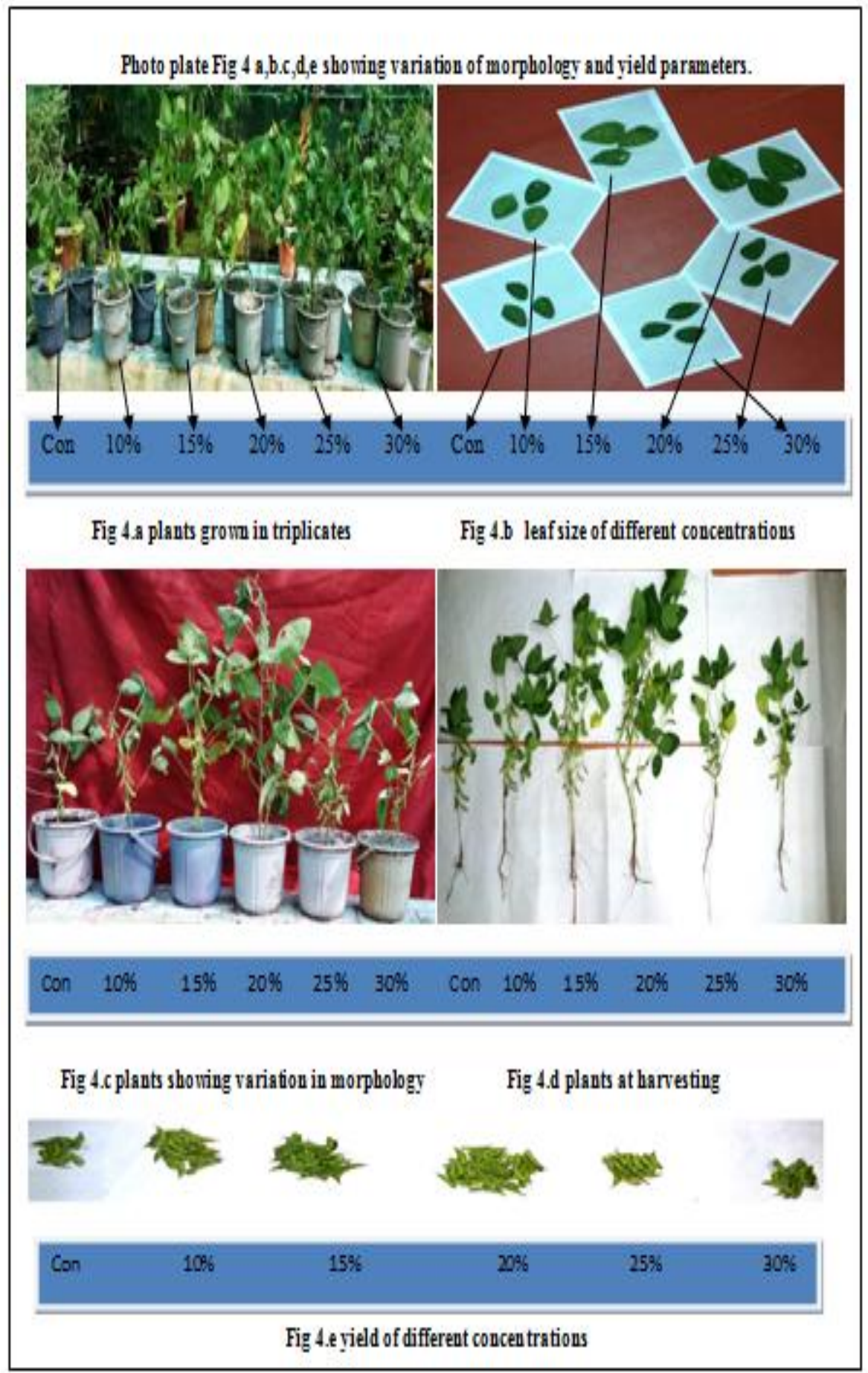

